\title{
Effect of Aggregate and Binder Type on the Functional and Durability Parameters of Lightweight Repair Mortars
}

\author{
Martina Záleská $^{1}\left(\mathbb{D}\right.$, Milena Pavlíková $^{1} \mathbb{D}$, Martin Vyšvařil $^{2}\left(\mathbb{D}\right.$ and Zbyšek Pavlík a $^{1, *(\mathbb{D})}$ \\ 1 Department of Materials Engineering and Chemistry, Faculty of Civil Engineering, \\ Czech Technical University in Prague, Thákurova 7, 16629 Prague, Czech Republic; \\ martina.zaleska@fsv.cvut.cz (M.Z.); milena.pavlikova@fsv.cvut.cz (M.P.) \\ 2 Institute of Chemistry, Faculty of Civil Engineering, Brno University of Technology, Žižkova 17, \\ 60200 Brno, Czech Republic; vysvaril.m@fce.vutbr.cz \\ * Correspondence: pavlikz@fsv.cvut.cz; Tel.: +420-224-354-371
}

Citation: Záleská, M.; Pavlíková, M.; Vyšvařil, M.; Pavlík, Z. Effect of Aggregate and Binder Type on the Functional and Durability Parameters of Lightweight Repair Mortars. Sustainability 2021, 13, 11780. https:// doi.org/10.3390/su132111780

Academic Editors: Nelson Soares and Luisa Dias Pereira

Received: 7 October 2021

Accepted: 22 October 2021

Published: 25 October 2021

Publisher's Note: MDPI stays neutral with regard to jurisdictional claims in published maps and institutional affiliations.

Copyright: (c) 2021 by the authors. Licensee MDPI, Basel, Switzerland. This article is an open access article distributed under the terms and conditions of the Creative Commons Attribution (CC BY) license (https:/ / creativecommons.org/licenses/by/ $4.0 /)$.

\begin{abstract}
The subject matter of the work presented here is the development and evaluation of novel lightweight mortars that meet the functional and technical criteria imposed on repair mortars. In a broad experimental campaign, lime, natural hydraulic lime, and lime-cement mortars were designed and tested. Lightweight aggregate, expanded perlite, granules from expanded glass and zeolite were used as full replacements for quartz sand. The hardened mortars were tested at the ages of 28 days and 90 days. The conducted tests and analyses were focused on the assessment of structural, mechanical, hygric and thermal parameters. The salt crystallization resistance and effect of salt presence on the hygroscopicity of the investigated mortars were also investigated. The use of lightweight aggregates in the composition of mortars resulted in their high porosity, low density, satisfactory mechanical parameters, improved water vapor transmission capability and water absorption. The mortars with expanded perlite and glass granulate were ranked among thermal insulation mortars of classes T1 and T2, respectively. The use of lightweight aggregates enabled the development of mortars with great durability in terms of salt action, which was almost independent of binder type. The ability to accommodate water vapor was increased by the effect, i.e., the use of lightweight aggregates and the presence of salt in mortars increased porous space. Taking into account the compatibility, functional, and technical criteria, lime- and natural hydraulic lime-based lightweight mortarswere classified as repair mortars, providing improved thermal performance. The lime-cement lightweight plasters can be recommended only for repair of building structures where cement and lime-cement materials were original applied.
\end{abstract}

Keywords: repair mortars; lightweight aggregate; hygrothermal performance; energy efficiency enhancement; salt crystallization resistance

\section{Introduction}

In Europe, housing and building stocks are considered highly unique as well as diverse; however, most of buildings are old and not energy-efficient. The heating and cooling of buildings is responsible for almost $40 \%$ of the total energy consumption in European Union (EU). EU achievement of its energy and climate targets is associated with its ambition to renovate building stock, giving priority to energy efficiency. At present, the renovation treatments and procedures in the EU address energy performance of existing stock of building only very rarely, with the weighted annual energy renovation rate at about $1 \%[1,2]$.

Great potential in terms of energy use reduction can be found in the renovation of cultural heritage buildings. Generally, the simplest and most frequently-used solution for improving the envelope of buildings is the External Thermal Insulation Composite System (ETICS) [3]. However, despite its unquestionable advantages, in the case of many older and historical buildings ETICS is often banned by the cultural heritage authorities due 
the emphasis on protection and preservation of the original architectural style and inbuilt materials [4]. The improvement of hygrothermal performance of building envelopes can also be solved by using thermal insulation rendering and plastering mortars, which are an important means of dealing with energy efficiency issues in the building field, especially in repair and renovation processes [5].

The main requirements for repair plasters include in particular high porosity, limited water absorption, high water vapor permeability, high flexibility, good adhesion, durability, and compatibility with the substrate [6,7]. The selection of materials compatible with historical structures is therefore very important and needs a complex solution. The binders most frequently used in restoration are air lime and natural hydraulic lime [8-10]; nevertheless, lime-cement mortars can be also considered for this application [11] taking into consideration the nature of originally applied materials. The basic functional requirements imposed on repair mortars are introduced in the EN 998-1 [12]; however, the required parameters are summarized in more detail in the WTA directive 2-9-04/D [13]. According to the WTA (International Association for Science and Technology of Building Maintenance and Monuments Preservation), the repair mortars should have a compressive strength $f_{\mathrm{c}}$ in the range of $1.5-5 \mathrm{MPa}$, water vapor diffusion resistance factor $\mu<12$, 24-h water absorption $W_{\mathrm{a}}>0.3 \mathrm{~kg} \cdot \mathrm{m}^{-2}$, and porosity $\psi>40 \%$.

Taking into account the aforementioned problems with high energy demand for operation of historical and heritage buildings, the important characteristics of renovation mortars should also include their thermal insulation parameters. In the literature there are many papers aiming to the use different insulating materials as aggregate or fibers in plaster composition in order to reduce thermal conductivity and thus improve thermal insulation performance $[4,7,14-23]$. It has been reported that the use of lightweight aggregates or fibers leads to a decrease in thermal conductivity and mechanical resistance and an increase in the porosity of hardened mortars. The improvement of both water vapor permeability and sorption parameters was also referenced. Let us note that in the case of thermal properties, emphasis must also be placed on their dependence on moisture content [7] which is substantial, especially for materials applied on damp substrates or subjected directly to moisture sources.

For repair mortars, longtime performance and maintenance of functional qualities, i.e., durability issues, are of particular importance. The durability of plasters is closely related to their resistance to water, freezing, and water-soluble salts, as salt crystallization is one of the most common causes of damage to inbuilt materials in historical and heritage buildings. The cyclic crystallization and dissolution of salts occurs in the pores; therefore, the high porosity of mortars positively affects their ability to absorb pressures linked with salt crystal growth [24-26]. However, it is not only overall porosity that has an important role in the susceptibility of mortars to salt decay, but also pore size distribution [25].

As requirements for repair mortars in terms of their functional, durability and sustainability parameters are still increasing, continuous research and development is necessary. Given the reasons above, and taking into account the need for thermal insulation repair renders and plasters, this research is aimed at the assessment of both binder type and lightweight aggregate type on the functional and durability parameters of repair mortars. On the basis of our review of the literature, the air lime, natural hydraulic lime and limecement blend were chosen as binders, and expanded perlite and zeolite as lightweight aggregate. A new commercially-delivered expanded glass granulate (Liaver) was tested as a prospective durable and thermal insulation filler. Comprehensive analysis of the macroand micro-structural, mechanical, transport and storage thermal and hygric properties of the prepared mortars was conducted, together with assessment of their durability in terms of salt crystallization resistance. Among the conducted tests and analyses, measurement of water vapor adsorption isotherms for mortars that were subjected to salt crystallization represents quite crucial and unique information for the application of the developed materials in salt-laden masonry. 


\section{Materials and Methods}

\subsection{Materials}

Mortar specimens were cast from three types of binders: hydrated lime CL 90-S (Čertovy Schody, Inc., Tmaň, Czech Republic, member of the Lhoist group), natural hydraulic lime (NHL 3.5, Zement- und Kalkwerke Otterbein GmbH \& Co. KG, Großenlüder-Müs, Germany), and Portland cement CEM I 42.5 R (Českomoravský cement, Inc., Radotín, Czech Republic, member of the HeidelbergCement Group). Washed quartz sand (the fine fraction 0/2 mm from Filtrační písky, Ltd., Chlum u Doks, Czech Republic), nonhydrophobized expanded perlite (EP $150 \mathrm{~PB}$, fraction $0 / 2 \mathrm{~mm}$ from PERLIT PRAHA, Ltd., Prague, Czech Republic), expanded glass (Liaver, fraction 0/2 $\mathrm{mm}$ from Liaver $\mathrm{GmbH} \&$ Co. KG, Ilmenaou, Germany), and natural zeolite (fraction 0/2 mm from Zeocem, Inc., Bystré, Slovakia) were applied as fine-grained aggregates.

\subsection{Chemical Composition and Phase Analysis of Initial Materials}

The chemical composition of initial materials presented in oxide form is introduced in Table 1. It was assessed with an Axios X-ray Fluorescence (XRF) spectrometer with $2.4 \mathrm{~kW}$ (Malvern Panalytical, Malvern, UK) and SuperQ V4.0 software. The mineralogical composition of materials (Table 2) was obtained by Empyrean X-ray Diffraction (XRD) spectrometer (Malvern Panalytical, UK). The quantitative phase analysis was performed according to the Rietveld method using the fundamental parameters approach. The internal standard $\left(\mathrm{CaF}_{2}\right)$ method was used to determine the amorphous phase content in the initial materials. Data evaluation was executed by the HighScore Plus software version 4.8 (Malvern Panalytical, UK). The acquired data show the hydrated lime was, as usual, fully crystalline with little $\mathrm{MgO}$ contamination. In contrast, NHL 3.5 and cement, with a typical representation of siliceous and aluminum minerals, contained a significant amount of amorphous phases. The basic physical properties and parameters of the used binders can be found in the authors' previous work [27]. The applied silica sand was highly pure without any clay or feldspathic contaminants. The chemical composition of expanded perlite (EP), expanded glass (EG), and natural zeolite (ZEO) showed a high content of $\mathrm{SiO}_{2}$ and $\mathrm{Al}_{2} \mathrm{O}_{3}$ supplemented by the expected higher content of $\mathrm{Na}_{2} \mathrm{O}$ and $\mathrm{CaO}$ in the case of EG. The lightweight aggregates contained large amounts of hydraulic oxides $\left(\mathrm{SiO}_{2}, \mathrm{Al}_{2} \mathrm{O}_{3}\right.$, $\mathrm{Fe}_{2} \mathrm{O}_{3}$ ) - EP 86\%, EG 73\%, ZEO 80\% respectively, which together with their high content of amorphous phase $(90.8 \%, 97.7 \% 30.2 \%)$ creates a very strong presumption in favor of pozzolanic reactivity.

\subsection{Physical Properties of Ligweight Aggregates}

The chosen physical properties of the lightweight aggregates used, as imparted by the manufacturers, are summarized in Table 3. The low powder (loose bulk) density and the thermal conductivity of EP and EG represent good prerequisites for the design and development of highly porous thermal insulation mortars.

Table 1. Chemical composition of initial materials (wt.\%).

\begin{tabular}{cccccccccccc}
\hline & $\mathbf{S i O}_{\mathbf{2}}$ & $\mathbf{A l}_{\mathbf{2}} \mathbf{O}_{\mathbf{3}}$ & $\mathbf{F e}_{\mathbf{2}} \mathbf{O}_{\mathbf{3}}$ & $\mathbf{C a O}$ & $\mathbf{M g O}$ & $\mathbf{K}_{\mathbf{2}} \mathbf{O}$ & $\mathbf{N a}_{\mathbf{2}} \mathbf{O}$ & $\mathbf{P}_{\mathbf{2}} \mathbf{O}_{5}$ & $\mathbf{T i O}_{\mathbf{2}}$ & $\mathbf{S O}_{\mathbf{3}}$ & $\mathbf{L O I}^{\mathbf{1}}$ \\
\hline Lime & 0.92 & 0.71 & 0.39 & 68.09 & 1.33 & 0.48 & 0.11 & 0.05 & 0.10 & 0.19 & 27.94 \\
NHL 3.5 & 12.76 & 4.12 & 1.47 & 59.87 & 2.79 & 1.13 & 0.09 & 0.15 & 0.05 & 0.15 & 15.28 \\
Cement & 21.26 & 5.08 & 3.64 & 61.48 & 0.86 & 0.91 & 0.12 & 0.08 & 0.29 & 2.42 & 4.17 \\
Quartz sand & 98.50 & 0.38 & 0.15 & 0.01 & 0.03 & 0.09 & 0.01 & 0.04 & 0.09 & 0.02 & 0.12 \\
EP & 68.02 & 16.04 & 1.91 & 4.54 & 0.41 & 2.50 & 4.62 & 0.14 & 0.10 & 0.02 & 0.33 \\
EG & 70.27 & 2.16 & 0.49 & 9.43 & 2.11 & 0.84 & 13.82 & 0.12 & 0.18 & 0.21 & 0.13 \\
ZEO & 67.46 & 11.73 & 1.37 & 2.84 & 0.73 & 3.02 & 0.50 & 0.03 & 0.17 & 0.01 & 11.57 \\
\hline
\end{tabular}

${ }^{1}$ Loss on ignition. 
Table 2. Minerals forming the initial materials (wt.\%).

\begin{tabular}{cccccccc}
\hline Mineral & Lime & NHL 3.5 & Cement & Quartz Sand & EP & EG & ZEO \\
\hline Alite & - & - & 50.6 & - & - & - & - \\
Albite & - & - & - & - & 1.9 & - & 2.6 \\
Aluminate & - & 2.7 & 3.9 & - & - & - & - \\
Anorthite & - & - & - & - & 3.2 & - & - \\
Biotite & - & - & - & - & 2.8 & - & 1.9 \\
Brownmillerite & - & 1.4 & 8.6 & - & - & - & - \\
Brucite & 0.5 & - & - & - & - & - & - \\
Calcite & 1.8 & 6.2 & - & - & - & - & - \\
Clinoptilolite & - & - & - & - & - & - & 50.5 \\
Cristobalite & - & - & - & - & - & - & 9.3 \\
Gypsum & - & - & 3.8 & - & - & - & - \\
Illite & - & - & - & - & - & - & 2.0 \\
Larnite & - & 22.5 & 4.9 & - & - & - & - \\
Portlandite & 97.1 & 41.3 & - & - & - & - & - \\
Quartz & - & - & - & 98.3 & 0.4 & 2.2 & 3.4 \\
Sanidine & - & - & - & - & 0.6 & - & - \\
Staurolite & - & - & - & 1.5 & - & - & - \\
Amorphous & - & 25.1 & 28.4 & - & 90.8 & 97.7 & 30.2 \\
phases & & & & & & & \\
\hline
\end{tabular}

Table 3. Selected parameters of used aggregates imparted by producers.

\begin{tabular}{cccc}
\hline Property & EP & EG & ZEO \\
\hline Loose bulk density $\left(\mathrm{kg} \cdot \mathrm{m}^{-3}\right)$ & 179 & 310 & 1020 \\
Water absorption $\left(\mathrm{l} \cdot \mathrm{m}^{-3}\right)$ & 348 & 25 & 270 \\
Thermal conductivity $\left(\mathrm{W} \cdot \mathrm{m}^{-1} \cdot \mathrm{K}^{-1}\right)$ & 0.04 & 0.07 & 0.16 \\
Thermal stability $\left({ }^{\circ} \mathrm{C}\right)$ & 900 & 750 & 450 \\
Water vapor diffusion resistance factor, $\mu$-value $(-)$ & 3 & 5 & - \\
Capillary evaporation $\left(\mathrm{g} \cdot \mathrm{h}^{-1}\right)$ & 0.36 & - & - \\
Compressive strength $(\mathrm{MPa})$ & 0.3 & 3 & 30 \\
pH $(-)$ & 7 & 7 & $7-8$ \\
\hline
\end{tabular}

\subsection{Assessment of Pozzolanic Activity of the Applied Aggregates}

Pozzolanic activity of the aggregates (Table 4 ) was tested by a modified Chapelle test method according to the standard NF P 18-513 [28]. The limit of consumed $\mathrm{Ca}(\mathrm{OH})_{2}$ for the consideration of the material as pozzolana active $\left(650 \mathrm{mg} \cdot \mathrm{g}^{-1}\right.$ [29]) was exceeded after 2-3 days of treatment in the case of EP; EG was the most pozzolana active of the three examined aggregates, and ZEO did not meet the condition of pozzolanicity even after 5 days of treatment. It was seen that the pozzolanic reaction of the aggregates evolved over time.

Table 4. Pozzolanic activity of used aggregates.

\begin{tabular}{cccc}
\hline $\begin{array}{c}\text { Pozzolanic Reaction Time } \\
\text { (Days) }\end{array}$ & \multicolumn{3}{c}{$\begin{array}{c}\text { Pozzolanic Activity } \\
\left(\mathbf{m g ~ C a}(\mathbf{O H})_{\mathbf{2}} / \mathbf{g}\right)\end{array}$} \\
\hline & EP & EG & ZEO \\
1 & 259 & 676 & 409 \\
2 & 468 & 972 & 428 \\
3 & 997 & 1077 & 453 \\
4 & 1072 & 1172 & 601 \\
5 & 1137 & 1234 & 646 \\
\hline
\end{tabular}




\subsection{Particle Size Distribution Analysis}

The particle size distribution of lightweight aggregates (Figure 1) was determined by Mastersizer 2000 laser particle analyzer (Malvern Panalytical, UK). To prevent segregation of aggregate particles, they were dispersed in acetone solution.

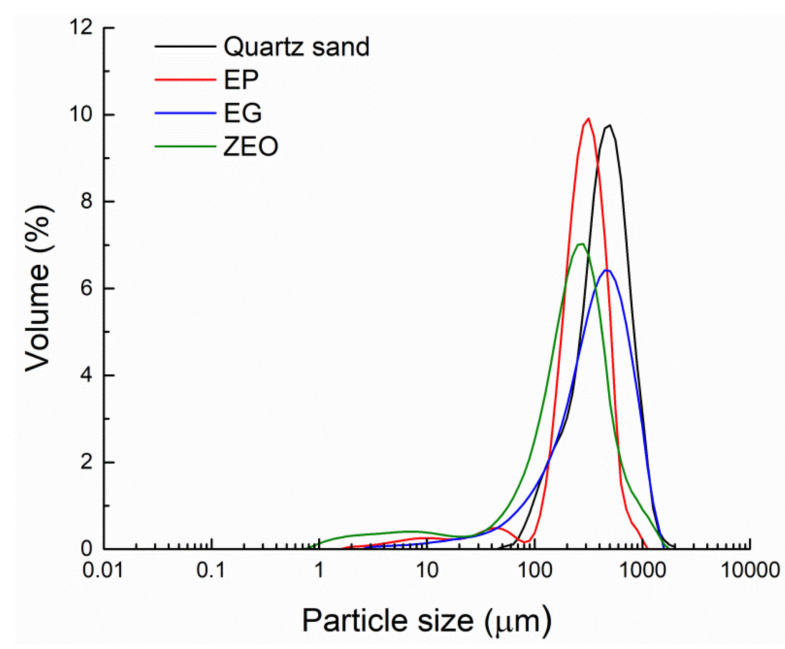

Figure 1. Particle size distribution of sand and lightweight aggregates.

\subsection{Microstructure of Aggregates}

The microstructure of aggregate particles (Figure 2) was investigated using scanning electron microscope (SEM) Tescan Mira3 (TESCAN Brno, Ltd., Brno, Czech Republic). Aggregate grains were embedded with epoxy resin, and after hardening, a sample with a fracture surface was obtained by breaking the material. EP and EG aggregate were very porous, with more massive partitions between the pores in the EG. The pore walls in the EP microstructure were thin and easily damaged. In contrast, the microstructure of ZEO was dense, composed of leaf sharp-edged crystals. The shape of EG particles was spherical, unlike EP and ZEO which had an irregular asymmetrical shape. The loose bulk density of particular lightweight aggregates (Table 3) completely reflected the differences in their microstructure.

\subsection{Sample Preparation and Curing}

The mortar specimens $(40 \mathrm{~mm} \times 40 \mathrm{~mm} \times 160 \mathrm{~mm}$ prisms and circular plate samples with a diameter of $120 \mathrm{~mm}$ and thickness of $30 \mathrm{~mm}$ ) were prepared with a constant binderto-aggregate volume ratio of 1:1.15. The binder/aggregate ratio of 1:1.15 was chosen after conversion of the 1:4 weight ratio in the reference lime mortar. This weight ratio is commonly used in the preparation of lime renders in research and practice. The dosage of mixing water was adjusted to main the normal consistency and similar workability of the mortars (flow $160 \pm 5 \mathrm{~mm}$; measured by the flow table test in accordance with standard EN 1015-3 [30]). Natural zeolite was not treated with water before the preparation of mortar samples, which resulted in higher amounts of mixing water necessary to achieve the required fresh mortar consistency. The weight composition of the designed mortars is given in Table 5. Hardened mortar specimens were demolded after $48 \mathrm{~h}$ and then cured in a wet chamber at temperature $T=(22 \pm 3)^{\circ} \mathrm{C}$ and a relative humidity $R H=(95 \pm 5) \%$ for 26 days. The samples were then stored under laboratory conditions at $T=(22 \pm 3){ }^{\circ} \mathrm{C}$, $R H=(50 \pm 5) \%$. During the entire ageing period, the samples were placed on plastic grids to make their surface as accessible as possible for carbonation. The planned tests were performed for samples aged 28 and 90 days, respectively. In the particular test, a minimum of five samples were tested. 

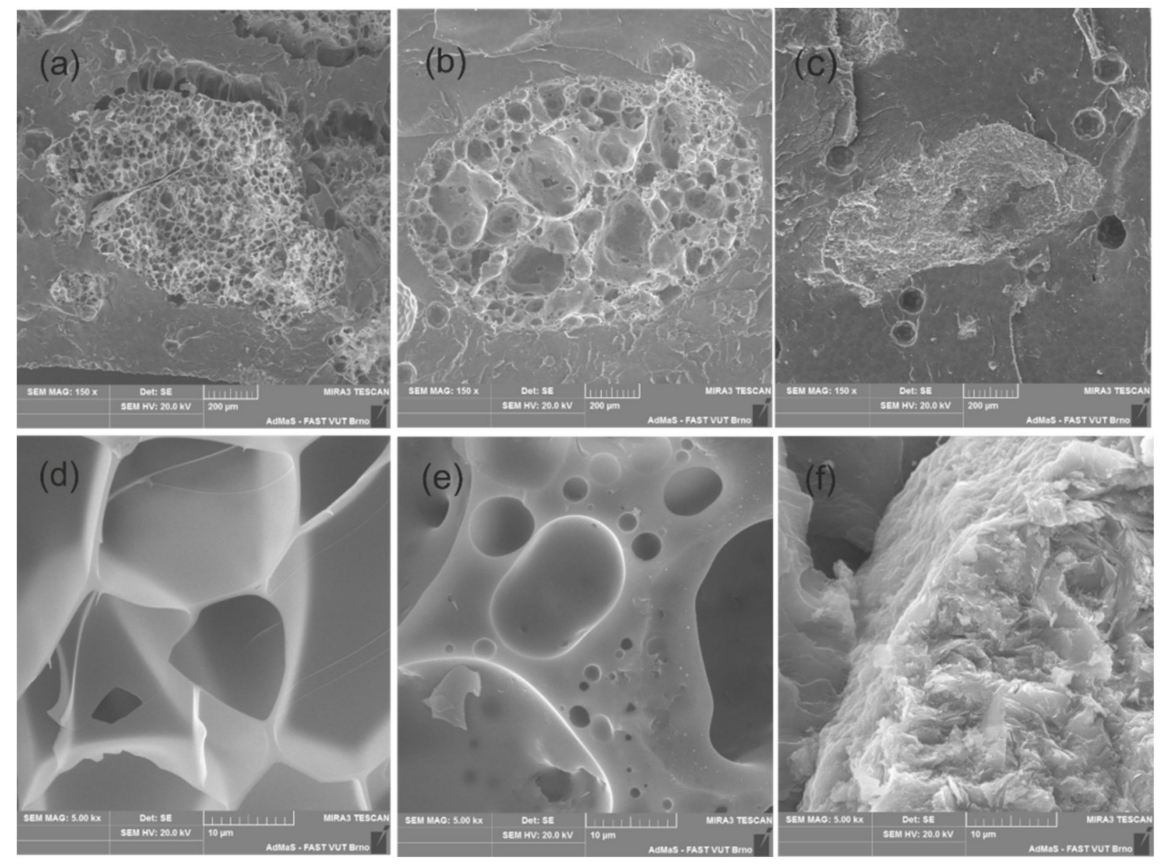

Figure 2. Microstructure of used aggregates taken by SEM. (a) EP, magnification $150 \times$; (b) EG magnification $150 \times$; (c) ZEO magnification $150 \times$; (d) detail of EP, magnification $5000 \times$; (e) detail of EG, magnification $5000 \times$; (f) detail of ZEO, magnification $5000 \times$.

Table 5. Proportioning of mortar mixtures.

\begin{tabular}{|c|c|c|c|c|c|c|c|c|}
\hline & Lime (g) & NHL 3.5 (g) & Cement (g) & Quartz Sand (g) & EP (g) & EG (g) & ZEO (g) & $\mathrm{H}_{2} \mathrm{O}(\mathrm{mL})$ \\
\hline LQ & 100 & - & - & 400 & - & - & - & 120 \\
\hline LEP & 100 & - & - & - & 142 & - & - & 35 \\
\hline LEG & 100 & - & - & - & - & 74 & - & 125 \\
\hline LZEO & 100 & - & - & - & - & - & 246 & 153 \\
\hline NHLQ & - & 100 & - & 340 & - & - & - & 75 \\
\hline NHLEP & - & 100 & - & - & 120 & - & - & 5 \\
\hline NHLEG & - & 100 & - & - & - & 62 & - & 75 \\
\hline NHLZEO & - & 100 & - & - & - & - & 208 & 115 \\
\hline LCQ & 50 & - & 50 & 280 & - & - & - & 72 \\
\hline LCEP & 50 & - & 50 & - & 100 & - & - & 18 \\
\hline LCEG & 50 & - & 50 & - & - & 52 & - & 75 \\
\hline LCZEO & 50 & - & 50 & - & - & - & 173 & 105 \\
\hline
\end{tabular}

\subsection{Testing of Hardened Mortars}

As basic macro-structural parameters, bulk and specific density, and total open porosity were determined. The dry bulk density $\rho_{\mathrm{b}}\left(\mathrm{kg} \cdot \mathrm{m}^{-3}\right)$ measurement was arranged in compliance with the European standard EN 1015-10 [31]. Firstly, the samples were vacuum dried (Vacucell, BMT, Brno, Czech Republic) at $60^{\circ} \mathrm{C}$ until achieving of their mass equilibrium (sample mass difference was $<0.1 \%$ ). The helium pycnometer Pycnomatic ATC (Porotec, Hofheim, Germany) was used to explore the specific density $\rho_{\mathrm{s}}\left(\mathrm{kg} \cdot \mathrm{m}^{-3}\right)$. The known values of bulk and specific density of a given sample were employed for the total open porosity $\psi(-)$ calculation [32]. The expanded combined uncertainties of the bulk density, specific density, and porosity determination were $1.4 \%, 1.2 \%$, and $2.0 \%$, respectively.

For the characterization of mechanical parameters, the testing of flexural and compressive strength together with the dynamic modulus of elasticity was performed according to the standard EN 1015-11 [33]. At first, the cured prisms with dimensions of $(40 \times 40 \times 160)$ $\mathrm{mm}$ were loaded with $50 \mathrm{~N} \cdot \mathrm{s}^{-1}$ in the three-point bending test to determine the flexural strength $f_{\mathrm{f}}(\mathrm{MPa})$. The sample fragments sizes of $(40 \times 40) \mathrm{mm}$ were used for the compres- 
sive strength $f_{\mathrm{c}}(\mathrm{MPa})$ measurement. The used uniaxial compression force $\left(100 \mathrm{~N} \cdot \mathrm{s}^{-1}\right)$ was applied on the cross section of the specimens. To specify the dynamic modulus of elasticity $E_{\mathrm{d}}(\mathrm{GPa})$, the Vikasonic apparatus (Schleinbinger Geräte, Buchbach, Germany) was employed. The expanded combined uncertainties of the mechanical parameters assessment were $1.4 \%, 1.4 \%$, and $2.3 \%$ for $f_{\mathrm{f}}, f_{\mathrm{c}}$, and $E_{\mathrm{d}}$, respectively. For the measurement of $\mathrm{f}_{\mathrm{f}}$ and $E_{\mathrm{d}}, 5$ standard prisms were used. In the compressive strength test, eight halves of broken prisms from the flexural strength measurement were examined.

The water and water vapor transport properties of the tested mortars were described with the apparent moisture diffusivity and the water vapor resistance factor. The onedimensional water suction experiment was performed on the $40 \mathrm{~mm}$ cubes according to the EN 1015-18 [34] to assess the water absorption coefficient $A_{\mathrm{W}}\left(\mathrm{kg} \cdot \mathrm{m}^{-2} \cdot \mathrm{s}^{-1 / 2}\right)$. This value, together with the known saturated moisture content, was used for the apparent moisture diffusivity $\mathrm{K}_{\mathrm{app}}\left(\mathrm{m}^{2} \cdot \mathrm{s}^{-1}\right)$ calculation according to the original procedure proposed by Kumaran [35]. The expanded combined uncertainty of the water absorption tests was $1.2 \%$, and that of the apparent moisture diffusivity was $2.9 \%$.

According to the EN ISO 12572 [36], the experiment of water vapor transport was arranged to determine the water vapor resistance factor $\mu(-)$ [36]. The circular samples of $120 \mathrm{~mm}$ in diameter and $30 \mathrm{~mm}$ of thickness were sealed to the cups and placed in the climatic chamber. In the case of the dry-cup experiment, the cup contained activated silica gel to ensure $(5 \pm 2) \%$ relative humidity. In the wet-cup test, the cup was filled using a saturated $\mathrm{KNO}_{3}$ solution to achieve $(93 \pm 2) \%$ relative humidity. The corresponding relative humidity in the climatic chamber was 50\%. The expanded combined uncertainty of the water vapor resistance factor assessment was $2.8 \%$.

The thermal analyzer ISOMET 2114 (Applied Precision, Bratislava, Slovakia), operating on the transient impulse technique principle, was employed to research the heat transport and storage parameters of the tested mortars [37]. For the measurement of the thermal conductivity $\lambda\left(\mathrm{W} \cdot \mathrm{m}^{-1} \cdot \mathrm{K}^{-1}\right)$ and the volumetric heat capacity $c_{\mathrm{V}}\left(\mathrm{J} \cdot \mathrm{m}^{-3} \cdot \mathrm{K}^{-1}\right)$, the surface probe was placed on the horizontal sample surface with the dimensions $(70 \times 70 \times 70) \mathrm{mm}$. The expanded combined uncertainty of the thermal conductivity and volumetric heat capacity measurement was 3\%.

The standard EN 12370 [38] was followed in order to assess the salt crystallization resistance of the investigated mortars. The real salinization of masonry materials was simulated by sodium chloride $(\mathrm{NaCl})$ and sodium sulfate (anhydrous $\mathrm{Na}_{2} \mathrm{SO}_{4}$ ) salt solutions, and with respect to standard recommendations, the concentration of each salt was chosen to be $2 \%$ (weight salt/weight dry specimen). Oven-dried 90-day specimens having dimensions of $(40 \times 40 \times 40) \mathrm{mm}$ were exposed to 10 crystallization cycles; each cycle was comprised of sample immersion into salt solution for $2 \mathrm{~h}$ and subsequent drying in an oven at $70{ }^{\circ} \mathrm{C}$ for at least $16 \mathrm{~h}$. After that, specimens were removed from the oven and cooled for $2 \mathrm{~h}$. Each sample was placed in its own polypropylene powder jar which was water and water vapor proof sealed. For the evaluation of the salt crystallization effect, loss or gain of salt exposed specimens was determined after 10 crystallization cycles followed by $24 \mathrm{~h}$ sample leaching in $200 \mathrm{~mL}$ of distilled water at $80^{\circ} \mathrm{C}$, followed by drying in an oven.

The sorption isotherms were investigated for the 90-day mortars after the crystallization test, where the total immersion time in distilled water or in a $\mathrm{NaCl} / \mathrm{Na}_{2} \mathrm{SO}_{4}$ solution with a concentration of $2 \mathrm{wt}$ \%/weight of sample was $20 \mathrm{~h}$. To characterize the water vapor adsorption capacity, the sorption isotherms were determined. The measurement was carried out on oven-dried fragments of samples which were placed in a climatic chamber at a temperature of $(23 \pm 1){ }^{\circ} \mathrm{C}$. The desiccator test method was performed according to the ISO 12571 [39]. The equilibrium relative humidity of $11 \%, 43 \%, 75 \%, 85 \%$, and $98 \%$ was maintained with the use of saturated solutions of $\mathrm{LiCl}, \mathrm{K}_{2} \mathrm{CO}_{3}, \mathrm{NaCl}, \mathrm{KCl}$, and $\mathrm{K}_{2} \mathrm{SO}_{4}$, respectively. Samples were periodically weighed until they achieved a constant mass and the gravimetric moisture content $u\left(\mathrm{~kg} \cdot \mathrm{kg}^{-1}\right)$, and the dependence of relative humidity was calculated. 


\section{Results and Discussion}

Where applicable, the acquired structural, mechanical, hygric, and thermal data measured for 28-days and 90-days mortars was evaluated as specified in the EN 998-1 [12] and the WTA directive 2-9-04/D [13].

\subsection{Structural Parameters}

The macro-structural parameters of the investigated mortars are introduced in Table 6. The lightening effect of the used alternative aggregates was quite apparent. Among the control mortars, lime-cement mortar exhibited the lowest porosity in both examined curing ages. The porosity of LQ mortar was only slightly higher than that of natural hydraulic lime-based mortar. Quantitatively, all lightened mortars yielded porosity $>40.0 \%$, which is the limit imposed on repair mortars by WTA directive 2-9-04/D [13]. Similarly, the bulk density of mortars with incorporated lightweight aggregates was well below $1400 \mathrm{~kg} \cdot \mathrm{m}^{-3}$. This criterion is also introduced in WTA directive 2-9-04/D [13]. The drop in bulk density was in compliance with the increase in the porosity, whereas these two parameters were results of two combined effects: (i) low loose bulk density of lightweight aggregates, i.e., their high porosity, and (ii) structural changes in the mortars due to the incorporation of lightweight aggregates. In general, application of lightweight aggregates gave less dense mortars meeting the demands for repair mortars. In respect to the presumed application of the developed mortars in salt and moisture laden masonry, their high porosity will enable safe salt accumulation and evaporation of stored water.

Table 6. The fundamental structural parameters of the hardened mortars.

\begin{tabular}{|c|c|c|c|c|c|c|}
\hline Material & $\begin{array}{c}\rho_{\mathrm{b}} \\
\left(\mathrm{kg} \cdot \mathrm{m}^{-3}\right)\end{array}$ & $\begin{array}{c}\rho_{\mathbf{b}} \\
\left(\mathrm{kg} \cdot \mathrm{m}^{-3}\right)\end{array}$ & $\begin{array}{c}\rho_{\mathrm{s}} \\
\left(\mathrm{kg} \cdot \mathrm{m}^{-3}\right)\end{array}$ & $\begin{array}{c}\rho_{\mathrm{s}} \\
\left(\mathrm{kg} \cdot \mathrm{m}^{-3}\right)\end{array}$ & $\begin{array}{c}\Psi \\
(\%)\end{array}$ & $\begin{array}{c}\Psi \\
(\%)\end{array}$ \\
\hline & 28 Days & 90 Days & 28 Days & 90 Days & 28 Days & 90 Days \\
\hline LQ & $1749 \pm 21$ & $1779 \pm 25$ & $2589 \pm 31$ & $2599 \pm 31$ & $32.4 \pm 0.6$ & $31.6 \pm 0.6$ \\
\hline LEP & $612 \pm 9$ & $641 \pm 9$ & $1378 \pm 17$ & $1419 \pm 17$ & $55.6 \pm 1.1$ & $54.9 \pm 1.1$ \\
\hline LEG & $616 \pm 9$ & $633 \pm 9$ & $1593 \pm 19$ & $1661 \pm 20$ & $61.3 \pm 1.2$ & $60.7 \pm 1.2$ \\
\hline LZEO & $1139 \pm 16$ & $1147 \pm 16$ & $2237 \pm 27$ & $2248 \pm 27$ & $49.1 \pm 1.0$ & $48.9 \pm 1.0$ \\
\hline NHLQ & $1757 \pm 25$ & $1809 \pm 25$ & $2584 \pm 31$ & $2601 \pm 31$ & $32.0 \pm 0.6$ & $30.5 \pm 0.6$ \\
\hline NHLEP & $588 \pm 8$ & $608 \pm 9$ & $1519 \pm 18$ & $1523 \pm 18$ & $61.3 \pm 1.2$ & $60.3 \pm 1.2$ \\
\hline NHLEG & $682 \pm 10$ & $701 \pm 10$ & $1658 \pm 20$ & $1672 \pm 20$ & $58.9 \pm 1.2$ & $58.1 \pm 1.2$ \\
\hline NHLZEO & $1161 \pm 16$ & $1179 \pm 17$ & $2120 \pm 25$ & $2123 \pm 25$ & $45.2 \pm 0.9$ & $44.5 \pm 0.9$ \\
\hline LCQ & $1815 \pm 25$ & $1851 \pm 26$ & $2521 \pm 30$ & $2529 \pm 30$ & $28.0 \pm 0.6$ & $26.8 \pm 0.5$ \\
\hline LCEP & $635 \pm 9$ & $707 \pm 10$ & $1618 \pm 19$ & $1726 \pm 21$ & $60.8 \pm 1.2$ & $59.0 \pm 1.2$ \\
\hline LCEG & $758 \pm 11$ & $778 \pm 11$ & $1628 \pm 20$ & $1636 \pm 20$ & $53.4 \pm 1.1$ & $52.5 \pm 1.1$ \\
\hline LCZEO & $1231 \pm 17$ & $1240 \pm 17$ & $2109 \pm 25$ & $2110 \pm 25$ & $41.6 \pm 0.8$ & $41.2 \pm 0.8$ \\
\hline
\end{tabular}

\subsection{Mechanical Parameters}

In Table 7, the results of the testing of the mechanical parameters of the hardened mortars are introduced. The values of the expanded combined uncertainty are too low to be presented. The improvement in the mechanical strength and stiffness with the curing age is well apparent for all tested mortars. The highest strength and stiffness were recorded for the reference lime-cement mortar LCQ. According to the EN 998-1 [12], it is ranked in category CS IV. The lightened lime-cement mortars LCEG and LCZO belong to category CS III, and LCEP was classified into strength class CS II. Natural hydraulic lime mortars are classified in category CS II and lime mortars in class CS I. Both the European standard EN 998-1 [12] and WTA directive 2-9-04/D [13] prescribe for repair mortars strength class CE II, which criterion was safely met by NHL mortars. In respect to the mechanical strength, cement-lime mortars except LCEP cannot be recommended for application as repair mortars due to their incompatibility with original materials of historical masonry. However, they can find use in repair and restoration of those buildings where cement-lime mortars were originally used. This is in agreement with the prevailing opinion of the 
cultural heritage authorities and those interested in renewal and conservation of older and historical building stock [40-42]. Since ancient times, mortars of different composition and structure have been used and these have been strongly influenced by the function and availability of local raw materials [43]. Among them, lime mortars enriched by various mineral admixtures and aggregates have been used since before Roman times in most construction and under different environmental conditions. Therefore, in order to meet compatibility requirements for the mortar taking into consideration the structural, historical, and environmental context [44-46], development of the lime-based repair mortars is of particular importance. Usually, the compressive strength of lime mortars does not comply with the requirements of the CS II category; however, there are many examples based on analysis of historical masonry where much lower compressive strength values are recommended for the repair of traditional lime rendering and plastering mortars. For example, Nogueira et al. [47] recommended for repair purposes mortars with a 90-day compressive strength in the range of 0.4-2.5 MPa. Similar compressive strength values were also adopted by Veiga at al. [48]. To this effect, the developed lime mortars can be considered efficient for restoration purposes, especially in restoring of lime-based mortar constructed buildings.

Table 7. The mechanical properties of the hardened mortars.

\begin{tabular}{|c|c|c|c|c|c|c|}
\hline Material & $\begin{array}{c}f_{\mathrm{f}} \\
(\mathrm{MPa})\end{array}$ & $\begin{array}{c}f_{\mathrm{f}} \\
(\mathrm{MPa})\end{array}$ & $\begin{array}{c}f_{\mathrm{c}} \\
(\mathrm{MPa})\end{array}$ & $\begin{array}{c}f_{\mathrm{c}} \\
(\mathrm{MPa})\end{array}$ & $\begin{array}{c}E_{\mathrm{d}} \\
(\mathrm{GPa})\end{array}$ & $\begin{array}{c}E_{\mathrm{d}} \\
(\mathrm{GPa})\end{array}$ \\
\hline & 28 Days & 90 Days & 28 Days & 90 Days & 28 Days & 90 Days \\
\hline LQ & 1.1 & 1.5 & 1.4 & 2.0 & 4.4 & 4.8 \\
\hline LEP & 0.4 & 0.5 & 0.5 & 0.8 & 0.7 & 1.0 \\
\hline LEG & 0.6 & 0.8 & 0.7 & 1.0 & 1.8 & 2.8 \\
\hline LZEO & 0.7 & 0.8 & 1.1 & 1.7 & 3.4 & 3.6 \\
\hline NHLQ & 1.2 & 1.9 & 4.2 & 5.3 & 4.6 & 5.2 \\
\hline NHLEP & 0.9 & 1.8 & 3.1 & 4.0 & 1.3 & 1.9 \\
\hline NHLEG & 1.0 & 1.8 & 3.3 & 4.6 & 4.0 & 4.4 \\
\hline NHLZEO & 1.1 & 1.9 & 4.3 & 5.5 & 3.9 & 4.8 \\
\hline LCQ & 2.5 & 2.8 & 7.8 & 8.9 & 10.9 & 11.2 \\
\hline LCEP & 1.2 & 2.0 & 2.9 & 3.7 & 1.8 & 2.3 \\
\hline LCEG & 1.7 & 1.9 & 5.3 & 7.3 & 3.8 & 5.0 \\
\hline LCZEO & 1.6 & 1.9 & 5.2 & 5.7 & 4.2 & 4.8 \\
\hline
\end{tabular}

The criterion for the modulus of elasticity of mortars intended to be used in repair applications is not introduced in either the EN 998-1 [12] or WTA directive 2-9-04/D [13]. This problem was addressed, e.g., by Papayianni [49], who has suggested a repair mortars modulus of elasticity in the range 2-6 GPa. This was safely met by all the studied mortars except material LEP, whose stiffness was too low, and the reference lime-cement mortar LCQ, which was too rigid for repair applications. Similar $\mathrm{E}_{\mathrm{d}}$ values were also reported by Torres at al. [50], who achieved, for natural hydraulic lime mortars with ceramic residues used as pozzolan and/or aggregate, a dynamic elasticity modulus from 1.5 GPa to 7.7 GPa. Accordingly, Garijo et al. [51] and Grilo at al. [52] obtained for natural hydraulic lime mortars a dynamic elasticity modulus of $4.7 \mathrm{GPa}$ and $4.1 \mathrm{GPa}$ respectively. Moreover, Garijo et al. [51] have also analyzed aerial lime mortar with an elasticity modulus of approx. 2.4 GPa.

\subsection{Hygric Properties}

The values of the water vapor resistance factor obtained in the wet-cup and drycup tests are introduced in Table 8 . The differences in the water vapor resistance factor obtained for the 28-day and 90-day mortars are small, mostly in the range of the expanded combined uncertainty. In the wet-cup arrangement of the test, water vapor transmission was accelerated, which is typical of the performance of porous building materials [53,54]. As the surface of the pores is partially or fully occupied by water molecules, i.e., surface 
bonding of transmitted water vapor molecules is reduced, the water vapor flux is bigger than in the case of free pore sites in the dry-cup test.

Table 8. The water vapor resistance factor of the hardened mortar samples.

\begin{tabular}{|c|c|c|c|c|}
\hline \multirow[t]{3}{*}{ Material } & \multicolumn{2}{|c|}{ Dry-Cup } & \multicolumn{2}{|c|}{ Wet-Cup } \\
\hline & \multicolumn{4}{|c|}{$\mu(-)$} \\
\hline & 28 Days & 90 Days & 28 Days & 90 Days \\
\hline LQ & $\mathbf{1 1 . 0} \pm 0.3$ & $\mathbf{1 0 . 9} \pm 0.3$ & $10.7 \pm 0.3$ & $10.5 \pm 0.3$ \\
\hline LEP & $9.2 \pm 0.3$ & $9.9 \pm 0.3$ & $7.3 \pm 0.2$ & $8.1 \pm 0.2$ \\
\hline LEG & $9.3 \pm 0.3$ & $9.6 \pm 0.3$ & $8.7 \pm 0.2$ & $8.8 \pm 0.2$ \\
\hline LZEO & $\mathbf{9 . 6} \pm 0.3$ & $\mathbf{9 . 3} \pm 0.3$ & $9.2 \pm 0.3$ & $8.7 \pm 0.2$ \\
\hline NHLQ & $12.4 \pm 0.3$ & $\mathbf{1 1 . 3} \pm 0.3$ & $10.7 \pm 0.3$ & $9.5 \pm 0.3$ \\
\hline NHLEP & $8.8 \pm 0.2$ & $8.9 \pm 0.2$ & $7.2 \pm 0.2$ & $7.5 \pm 0.2$ \\
\hline NHLEG & $\mathbf{1 0 . 3} \pm 0.3$ & $\mathbf{1 0 . 2} \pm 0.3$ & $\mathbf{9 . 0} \pm 0.3$ & $\mathbf{9 . 0} \pm 0.3$ \\
\hline NHLZEO & $\mathbf{1 1 . 3} \pm 0.3$ & $\mathbf{1 1 . 2} \pm 0.3$ & $9.7 \pm 0.3$ & $9.8 \pm 0.3$ \\
\hline LCQ & $22.3 \pm 0.6$ & $20.9 \pm 0.6$ & $21.0 \pm 0.6$ & $19.6 \pm 0.5$ \\
\hline LCEP & $13.9 \pm 0.4$ & $12.6 \pm 0.4$ & $\mathbf{9 . 4} \pm 0.3$ & $8.4 \pm 0.2$ \\
\hline LCEG & $18.4 \pm 0.5$ & $17.1 \pm 0.5$ & $17.1 \pm 0.5$ & $16.5 \pm 0.5$ \\
\hline LCZEO & $19.3 \pm 0.5$ & $18.4 \pm 0.5$ & $19.3 \pm 0.5$ & $18.9 \pm 0.5$ \\
\hline
\end{tabular}

In compliance with the WTA directive 2-9-04/D [13] and the EN 998-1 [12], the water vapor resistance factor of repair mortars is prescribed to be $<12$ or $<15$, respectively. In Table $8, \mu$ values lower than WTA limit are marked in bold. Based on analysis of acquired data, mortars based on lime hydrate and natural hydraulic lime were found to be highly permeable for water vapor, and their permeability was significantly increased by the use of lightweight aggregates. These mortars are thus well applicable in damp masonry, where they will enable the drying of contained moisture and improve the hygric performance of the treated structure. Similar high water vapor permeability of lime and hydraulic lime-based mortars has been reported, e.g., Silva et al. [55], González-Sánches et al. [56], Barnat-Hunek et al. [57], and Torres et al. [58]. On the contrary, the lime-cement mortars yielded $\mu$ values higher than required for repair mortars. However, the improvement in water vapor permeability with the use of lightweight aggregates was also visible for these materials. In the case of wet-cup test results, LCEP mortar even met the limit required by WTA directive 2-9-04/D [13]. Therefore, these mortars can be recommended for repair of masonry built from cement-lime mortars or in the construction of new buildings.

The ability to transport water in its liquid phase was characterized by the assessment of the water absorption coefficient $A_{\mathrm{w}}$ and the apparent moisture diffusivity $\kappa_{\mathrm{app}}$. The measured data are presented in Table 9. In comparison with the reference mortars, the use of lightweight aggregates accelerated liquid water transport, which is in agreement with the porosity data and results of the water vapor transmission test. As introduced in the EN 998-1 [12], mortars for repair purposes must have $A_{\mathrm{w}} \geq 0.3 \mathrm{~kg} \cdot \mathrm{m}^{-2} \cdot \mathrm{min}^{-1 / 2}$ $\left(0.038 \mathrm{~kg} \cdot \mathrm{m}^{-2} \cdot \mathrm{s}^{-1 / 2}\right)$. This criterion was safely fulfilled by all lightweight mortars. In light of these results, the developed lightweight mortars are well applicable for moisture and salt laden masonry, where they can contribute to the transport of water and salt solution to the evaporating zone in the mortar layer and thus mitigate the presence of water, with its contained pollutants, in the repaired masonry.

\subsection{Heat Transport and Storage Properties}

Thermal conductivity and volumetric heat capacity plotted as functions of saturation rate are introduced in Figures 3 and 4. As the differences in both investigated thermal parameters measured for the 28-day and 90-day samples were small, only the results obtained for 90-day samples are presented. With increasing moisture content, both the thermal conductivity and volumetric heat capacity were greatly enhanced due to the high thermal conductivity and specific heat of water, which penetrated the pores of the examined 
mortars. In practical application of these materials in repair of damp masonry, this material behavior must be taken into consideration, as the moisture presence may deteriorate overall hygrothermal performance of the treated structure. The use of lightweight aggregates in mortar composition led to a large decrease in both thermal parameters due to the higher porosity of these aggregates compared to the reference quartz sand, and to the high porosity of the lightweight mortars themselves. In the dry state, the lowest thermal conductivity among control materials was exhibited by natural hydraulic lime-based mortar; the thermal conductivity of lime mortar was slightly higher, and the highest value of the thermal conductivity was yielded by lime-cement mortar, which had the lowest porosity. On the contrary, the saturated thermal conductivity was the lowest for lime mortar LQ. The differences in the dry thermal conductivity of lightweight mortars were lower. The best thermal insulation performance was recorded for mortars with EP and EG aggregates, whose dry thermal conductivity varied in the range $0.1-0.16 \mathrm{~W} \cdot \mathrm{m}^{-1} \cdot \mathrm{K}^{-1}$. Such low thermal conductivity was reported, e.g., for expanded polystyrene particle mortars [59], and later for closed expanded perlite and vitrified bead mortars containing natural fibers [60]. According to the EN 998-1 [12], this ranked these mortars among thermal insulation mortars in category $\mathrm{T} 1$ or T2, respectively. In the present technical standards and directives, there are no requirements for the thermal parameters of repair mortars; however, their low thermal conductivity can bring further benefits in terms of the thermal efficiency of refurbished buildings. The biggest drop in dry volumetric heat capacity was observed in lime and natural hydraulic lime mortars lightened with EP and EG. The use of zeolite reduced the volumetric heat capacity to a lower extent, i.e., 15.8\% for LZEO, 7.9\% for NHLZEO, and 15.2\% in case of LCZEO mortar, respectively. Rather than the aggregate type, the prevailing factor affecting the volumetric heat capacity of moistened samples was the saturation ratio. For the fully water saturated samples, the increase in the volumetric capacity varied in the range of $24.7-251.2 \%$ for lime mortars, $20.7-250 \%$ for NHL mortars, and $15.7-178.9 \%$ for lime-cement mortars, respectively.

\subsection{Salt Crystallization Resistance}

The mass loss of samples evoked by processes taking place within salt crystallization in the porous space of the hardened mortars is summarized in Table 10. The contribution of the applied lightweight aggregates to the overall resistance of the examined mortars against harmful salt action is well apparent. Due to the high porosity of the tested materials, which was enhanced by the porosity of lightweight fillers, high salt crystallization resistance was achieved. This finding is highly favorable for the intended application of the lightened mortars in repair works, including in structures where the presence of salt is expected.

Table 9. The water transport parameters of the hardened mortars.

\begin{tabular}{|c|c|c|c|c|}
\hline \multirow[t]{2}{*}{ Material } & \multicolumn{2}{|c|}{$\begin{array}{c}A_{\mathrm{w}} \\
\left(\mathrm{kg} \cdot \mathrm{m}^{-2} \cdot \mathrm{s}^{-1 / 2}\right)\end{array}$} & \multicolumn{2}{|c|}{$\begin{array}{c}\kappa_{\text {app }} \\
\left(\mathrm{m}^{2} \cdot \mathrm{s}^{-1}\right)\end{array}$} \\
\hline & 28 Days & 90 Days & 28 Days & 90 Days \\
\hline LQ & 0.30 & 0.29 & $8.61 \times 10^{-7}$ & $7.32 \times 10^{-7}$ \\
\hline LEP & 0.33 & 0.31 & $1.41 \times 10^{-6}$ & $1.23 \times 10^{-6}$ \\
\hline LEG & 0.32 & 0.31 & $1.27 \times 10^{-6}$ & $1.19 \times 10^{-6}$ \\
\hline LZEO & 0.37 & 0.35 & $2.11 \times 10^{-6}$ & $1.98 \times 10^{-6}$ \\
\hline NHLQ & 0.29 & 0.24 & $8.40 \times 10^{-7}$ & $5.01 \times 10^{-7}$ \\
\hline NHLEP & 0.52 & 0.51 & $2.01 \times 10^{-6}$ & $1.98 \times 10^{-6}$ \\
\hline NHLEG & 0.30 & 0.27 & $1.35 \times 10^{-6}$ & $1.11 \times 10^{-6}$ \\
\hline NHLZEO & 0.34 & 0.33 & $2.35 \times 10^{-6}$ & $2.21 \times 10^{-6}$ \\
\hline LCQ & 0.12 & 0.11 & $3.96 \times 10^{-7}$ & $3.63 \times 10^{-7}$ \\
\hline LCEP & 0.18 & 0.15 & $2.48 \times 10^{-7}$ & $1.84 \times 10^{-7}$ \\
\hline LCEG & 0.14 & 0.13 & $3.32 \times 10^{-7}$ & $2.98 \times 10^{-7}$ \\
\hline LCZEO & 0.25 & 0.23 & $5.70 \times 10^{-7}$ & $4.84 \times 10^{-7}$ \\
\hline
\end{tabular}




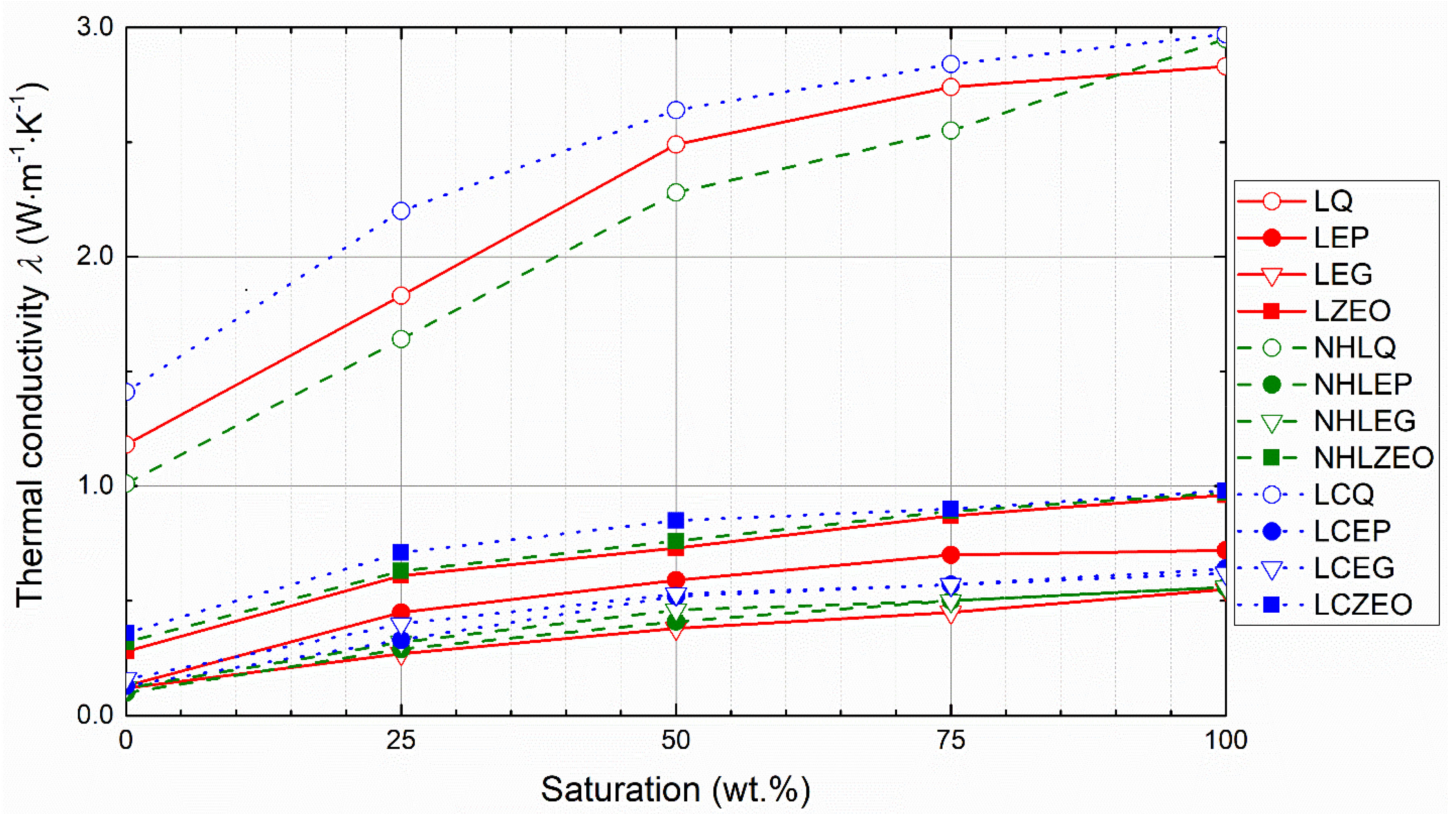

Figure 3. Thermal conductivity of the hardened mortars.

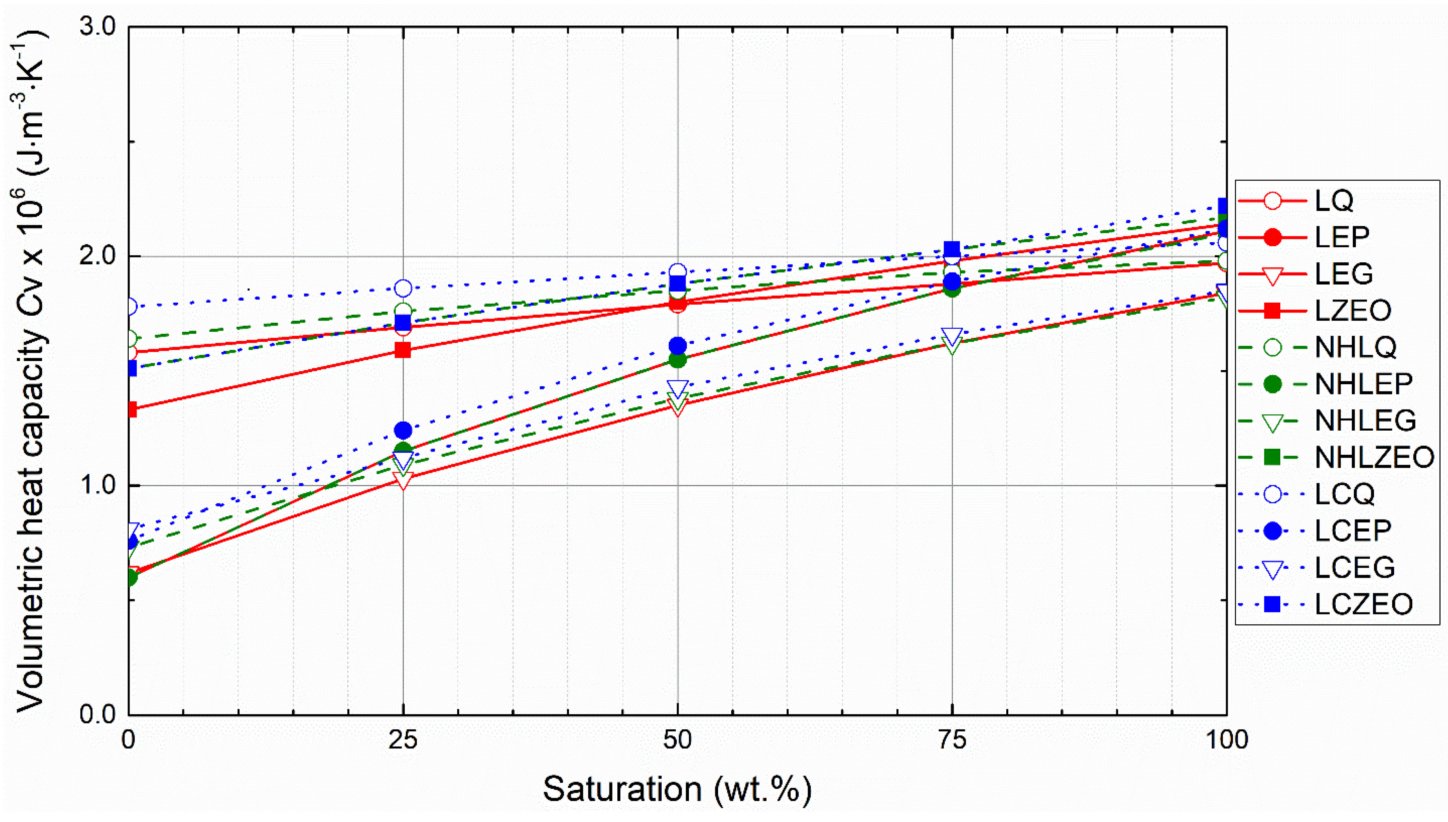

Figure 4. Volumetric heat capacity of the hardened mortars.

\subsection{Sorption Isotherms}

The sorption isotherms measured by the desiccator method of the water vapor storage assessment are plotted in Figures 5-7. In this case, the effect of the binder type was not dominant in affecting the water vapor storage. Typically, the use of lightweight aggregate increased the rate of water vapor accumulation, whereas the highest tendency to absorb water vapor was exhibited by mortars with zeolite. This is likely due to the high open porosity of zeolite particles and their complicated morphology with free binding sites for water molecules (see Figure 2). Mortar samples that did not undergo salt crystallization testing show the lowest values of adsorbed moisture; the shape of adsorption isotherms was almost linear, up to approximately $70 \%$ of $\mathrm{RH}$. After that, the capillary condensation phenomenon prevailed over multilayer adsorption, resulting in increased water vapor adsorption and finally in hygroscopic moisture content of the particular investigated materials. 
Table 10. Mass loss (wt.\%) of the hardened mortar samples incurred by salt crystallization.

\begin{tabular}{ccc}
\hline Mortar & \multicolumn{3}{c}{ Mass Loss (wt.\%) } \\
\hline LQ & $\mathbf{N a C l}$ & $\mathbf{N a}_{\mathbf{2}} \mathbf{S O}_{\mathbf{4}}$ \\
\hline LEP & 0.44 & 0.18 \\
LEG & 0.25 & 0.30 \\
LZEO & 0.29 & 0.16 \\
NHLQ & 0.35 & 0.31 \\
NHLEP & 0.23 & 0.16 \\
NHLEG & 0.08 & 0.07 \\
NHLZEO & 0.19 & 0.13 \\
LCQ & 0.20 & 0.18 \\
LCEP & 0.29 & 0.16 \\
LCEG & 0.08 & 0.11 \\
LCZEO & 0.12 & 0.14 \\
& 0.14 & 0.11 \\
\hline
\end{tabular}

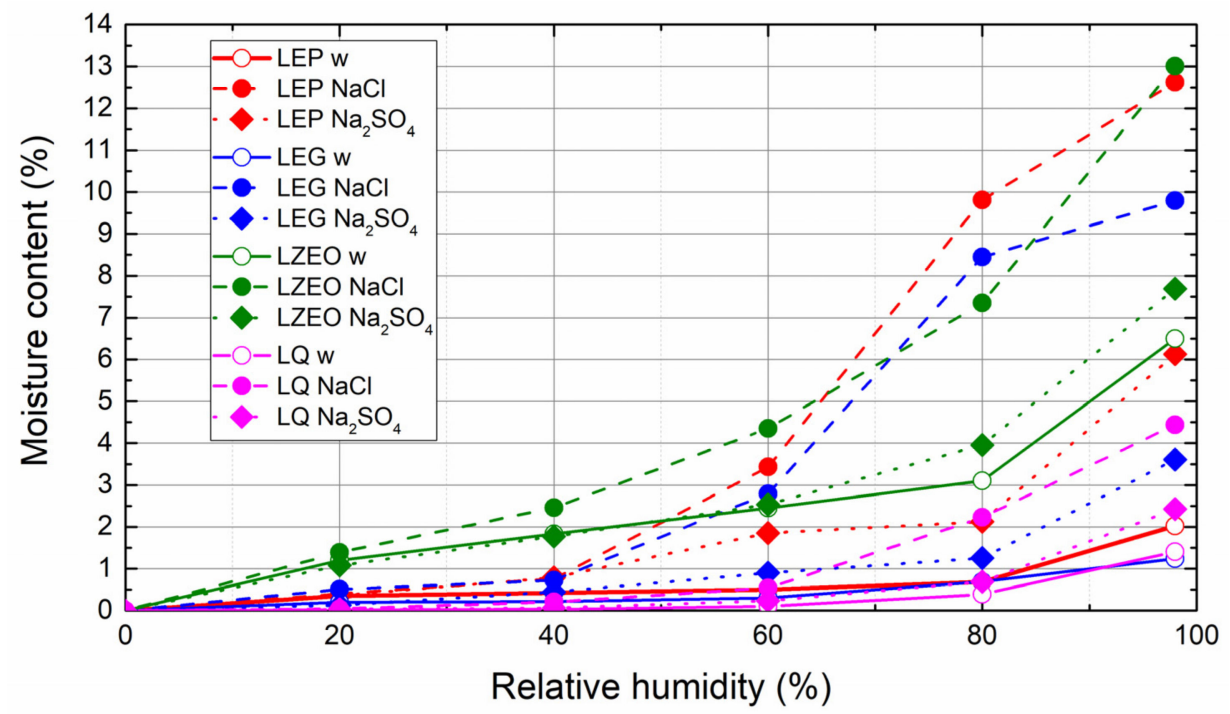

Figure 5. Sorption isotherms of lime mortars.

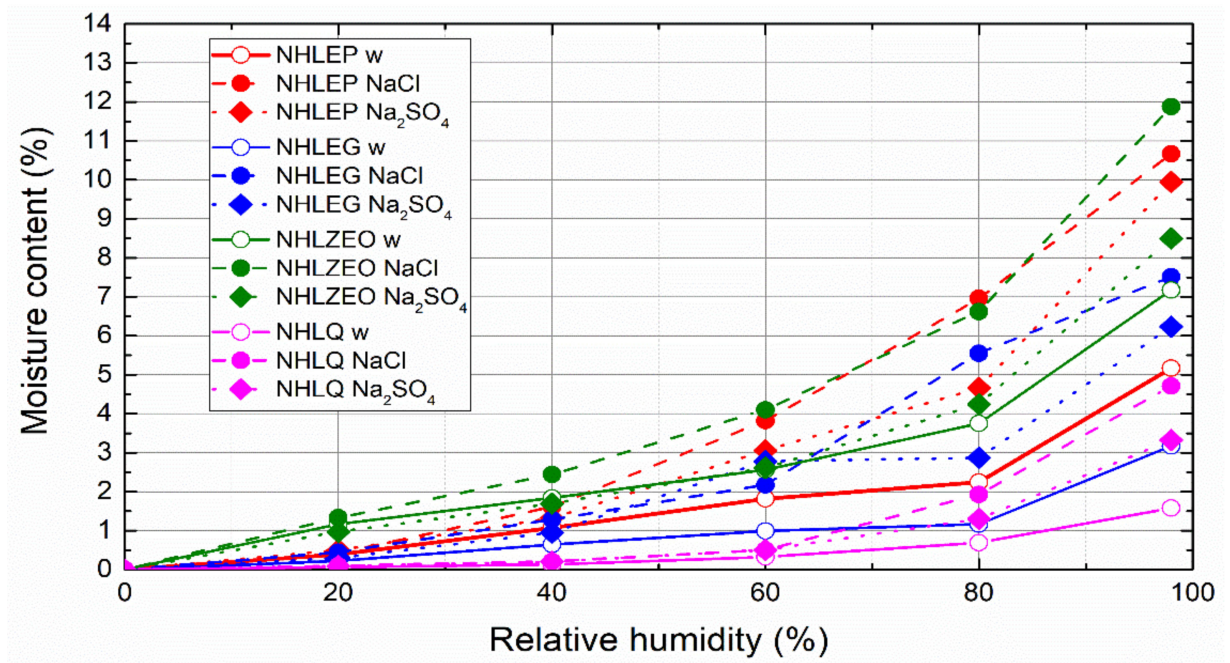

Figure 6. Sorption isotherms of natural hydraulic lime mortars. 


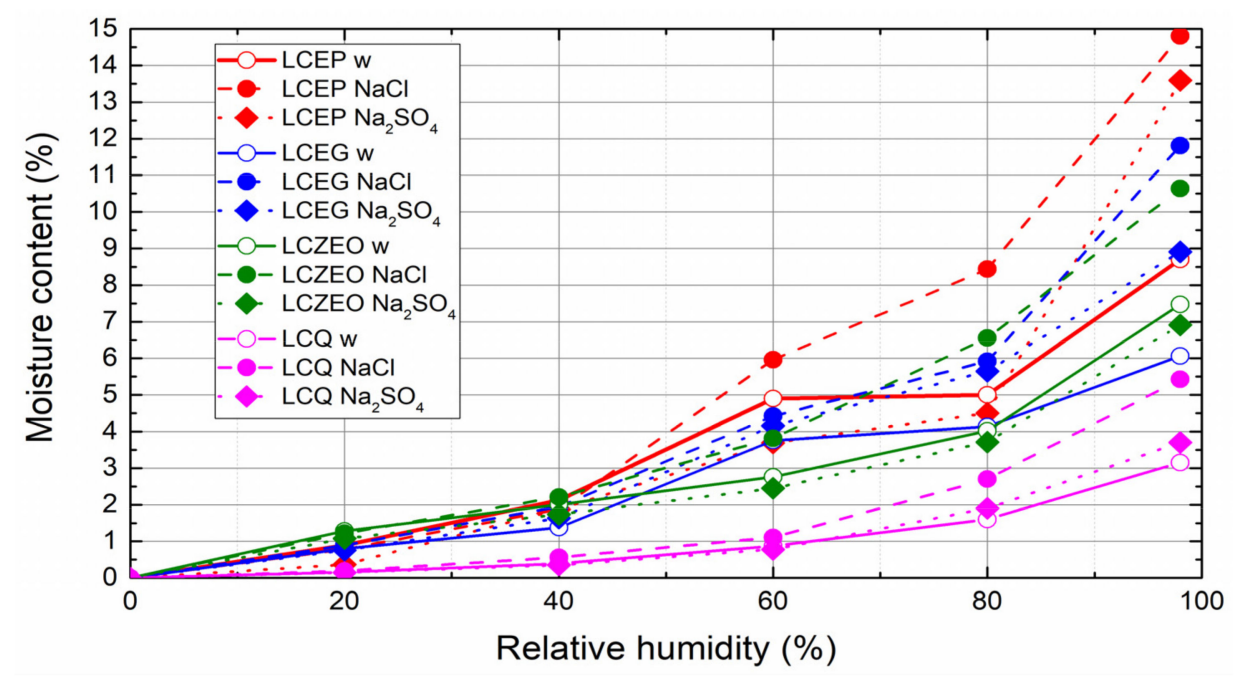

Figure 7. Sorption isotherms of lime-cement mortars.

The rate of water vapor accumulation was greatly enhanced by the presence of $\mathrm{NaCl}$ in the porous space of examined samples. In addition, $\mathrm{Na}_{2} \mathrm{SO}_{4}$ increased the moisture content values of the adsorption isotherms; however, in this case the differences in the accumulated moisture were much lower compared to that of $\mathrm{NaCl}$. Nevertheless, it must always be considered that the hygroscopic behavior of inbuilt materials affects the overall hygrothermal building performance, and thus energy consumption. Therefore, for buildings exposed to salt action, e.g., in marine atmospheric zones, or older buildings suffering from inorganic salt presence coming from underground water, construction materials themselves, housing of farm animals, winter maintenance of roads and pavements, etc., it is necessary to study the impact of salts on the hygroscopic performance of repair mortars [61]. In this respect, the acquired sorption isotherms represent valuable and unique information for materials research and construction practice. The water vapor sorption capacity of salt laden mortars corresponds with the efflorescence (crystallization) and deliquescence relative humidity of $\mathrm{Na}_{2} \mathrm{SO}_{4}$ and $\mathrm{NaCl}$, respectively [62]. As introduced in the literature, deliquescence of $\mathrm{Na}_{2} \mathrm{SO}_{4}$ and $\mathrm{NaCl}$ is at $\approx 84 \%$ and $75 \%$, respectively. The crystallization of these salts is reported at $\approx 57 \%$ and $43 \%[63,64]$. The referred specific relative humidities were well identified in the measured adsorption isotherms, and resulted in the great water vapor sorption capacity of these materials.

\section{Conclusions}

The effect of binder and aggregate type on the technical, functional, and durability characteristics of newly developed lightweight mortars was investigated. The broad experimental campaign comprised assessment of the structural, thermal, hygric, and mechanical parameters of the hardened mortars. Specific attention was paid to evaluation of the durability of the examined mortars against salt crystallization and analysis of the effect of salts on their hygroscopicity. The following results and findings can be highlighted:

(i) Application of lightweight aggregates enabled the development of highly porous and low-density materials meeting the requirements imposed on repair mortars.

(ii) With respect to mechanical performance, the lime and natural hydraulic lime-based mortars were found applicable for repair purposes even in historical masonry, where compatibility and functional criteria must be always attentively considered. Limecement mortars were too rigid and dense for such purposes.

(iii) Lime and natural hydraulic lime mortars were well permeable for water vapor and the use of lightweight aggregate even accelerated water vapor transport. These materials are therefore proper for application in damp masonry, where they can ensure drying of the contained water and thus improve the overall hygrothermal performance of the treated structure. As lime-cement mortar with expanded perlite 
met the requirements for water vapor resistance factor introduced in WTA directive 2-9-04/D, the lightweight lime-cement materials can be recommended for repair of masonry built with cement-lime mortar as well in the construction of new buildings.

(iv) For the lightweight mortars, water absorption was greatly increased, and based on the water absorption coefficient values, these can be classified as repair mortars applicable in the repair of damp buildings.

(v) The use of EP and EG resulted in the great improvement of thermal conductivity. Mortars with these types of aggregate were therefore ranked among thermal insulation mortars in class T1 or T2, respectively.

(vi) Independently of the binder type, all lightweight mortars have shown excellent resistance against salt crystallization, which is favorable for their presumed use in repair and restoration works.

(vii) The water vapor adsorption capacity of the reference mortars was enhanced by two effects: (a) incorporation of lightweight aggregates (the highest hygroscopicity was measured for zeolite-modified mortars), and (b) presence of $\mathrm{NaCl}$ and $\mathrm{Na}_{2} \mathrm{SO}_{4}$. The effect of salination on the overall water vapor adsorption rate and the hygrothermal function of materials must always be considered, especially when repairing older buildings, where salts can be present and originate from several sources.

With a view to the above highlighted findings, the following conclusion was drawn: The lime- and natural hydraulic lime-based mortars lightened with expanded perlite, expanded glass or zeolite can be classified as repair mortars meeting the functional and technical criteria of WTA directive 2-9-04/D and EN 998-1. Moreover, these mortars can help to improve the thermal insulation function of buildings, and are sufficiently resistant to be applicable in repair and renovation of salt laden structures.

Author Contributions: Conceptualization, M.P., M.V. and Z.P.; methodology, M.P., M.V. and Z.P.; investigation, M.Z., M.P., M.V. and Z.P.; funding acquisition, M.V. and Z.P.; data curation, M.Z., M.P. and Z.P.; writing—original draft preparation, M.Z., M.P., M.V. and Z.P.; writing-review and editing, M.P. and Z.P.; supervision, M.P., M.V. and Z.P.; project administration, M.P. and M.V. All authors have read and agreed to the published version of the manuscript.

Funding: This research was funded by the CZECH SCIENCE FOUNDATION, grant number 2106582S-Experimental and computational analysis of salt transport, accumulation, and crystallization in non-hydrophobized rendering mortars.

Institutional Review Board Statement: Not applicable.

Informed Consent Statement: Not applicable.

Data Availability Statement: The data presented in this study are available on request from the corresponding author. The data are not publicly available due to privacy.

Conflicts of Interest: The authors declare no conflict of interest. The funders had no role in the design of the study; in the collection, analyses, or interpretation of data; in the writing of the manuscript, or in the decision to publish the results.

\section{References}

1. Commission Recommendation (EU) 2019/786 of 8 May 2019 on Building Renovation. Available online: https:/ / eur-lex.europa. eu/eli/reco/2019/786/oj (accessed on 17 June 2021).

2. Communication from the Commission to the European Parliament, the Council, the European Economic and Social Committee and the Committee of the Regions-A Renovation Wave for Europe. 2020. Available online: https:/ / eur-lex.europa.eu/legalcontent/EN/TXT/?qid=1603122220757\&uri=CELEX:52020DC0662 (accessed on 17 June 2021).

3. Sulakatko, V.; Liisma, E.; Soekov, E. Increasing construction quality of external thermal insulation composite system (ETICS) by revealing on-site degradation factors. Procedia Environ. Sci. 2017, 38, 765-772. [CrossRef]

4. Záleská, M.; Pavlíková, M.; Pivák, S.A.; Lauermannová, A.M.; Jankovský, O.; Pavlík, Z. Lightweight vapor-permeable plasters for building repair: Detailed experimental analysis of the functional properties. Materials 2021, 14, 2613. [CrossRef]

5. Barbero, S.; Dutto, M.; Ferrua, C.; Pereno, A. Analysis of existent thermal insulating plasters towards innovative applications: Evaluation methodology for real cost-performance comparison. Energy Build. 2014, 77, 40-47. [CrossRef] 
6. Arizzi, A.; Viles, H.; Cultrone, G. Experimental testing of the durability of lime-based mortars used for rendering historic buildings. Constr. Build. Mater. 2012, 28, 807-818. [CrossRef]

7. Vyšvařil, M.; Pavlíková, M.; Záleská, M.; Pivák, A.; Žižlavský, T.; Rovnaníková, P.; Bayer, P.; Pavlík, Z. Non-hydrophobized perlite renders for repair and thermal insulation purposes: Influence of different binders on their properties and durability. Constr. Build. Mater. 2020, 263, 120617. [CrossRef]

8. Barbero-Barrera, M.M.; Maldonado-Ramos, L.; Van Balen, K.; García-Santos, A.; Neila-Gonzáles, F.J. Lime render layers: An overview of their properties. J. Cult. Herit. 2014, 15, 326-330. [CrossRef]

9. Bozkurt, T.S.; Demirkale, S.Y. The experimental research of sound absorption in plasters produced with perlite aggregate and natural hydraulic lime binder. Acoust. Aust. 2020, 48, 375-393. [CrossRef]

10. Aškrabič, M.; Vyšvařil, M.; Zakić, D.; Savić, A.; Stevanović, B. Effects of natural zeolite addition on the properties of lime putty-based rendering mortars. Constr. Build. Mater. 2021, 270, 121363. [CrossRef]

11. Pacheco-Torgal, F.; Faria, J.; Jalali, S. Some considerations about the use of lime-cement mortars for building conservation purposes in Portugal: A reprehensible option or a lesser evil? Constr. Build. Mater. 2012, 30, 488-494. [CrossRef]

12. European Committee for Standardization (CEN). Specification for Mortar for Masonry_Part 1: Rendering and Plastering Mortar; EN 998-1; European Committee for Standardization (CEN): Brussels, Belgium, 2016.

13. WTA. Wissenschaftlich-Technische Arbeitsgemeinschaft für Bauwerkserhaltung und Denkmalpflege e.V. In Sanierputzsysteme; Merkblatt 2-9-04/D; WTA Publications: Pfaffenhofen an der Ilm, Germany, 2005.

14. Ashour, T.; Wieland, H.; Georg, H.; Bockisch, F.-J.; Wu, W. The influence of natural reinforcement fibres on insulation values of earth plaster for straw bale buildings. Mater. Design. 2010, 31, 4676-4685. [CrossRef]

15. Ismail, B.; Belayachi, N.; Hoxha, D. Optimizing performance of insulation materials based on wheat straw, lime and gypsum plaster composites using natural additives. Constr. Build. Mater. 2020, 254, 118959. [CrossRef]

16. Gencel, O.; del Coz Diaz, J.J.; Sutcu, M.; Koksal, F.; Rabanal, F.P.A.; Martínez-Barrera, G. A novel lightweight gypsum composite with diatomite and polypropylene fibers. Constr. Build. Mater. 2016, 113, 732-740. [CrossRef]

17. Corinaldesi, V.; Donnini, J.; Nardinocchi, A. Lightweight plasters containing plastic waste for sustainable and energy-efficient building. Constr. Build. Mater. 2015, 94, 337-345. [CrossRef]

18. Styzeń, J.; Barnat-Hunek, D.; Panek, R.; Franus, W. The microstructural and physical properties of renovation renders with clinoptilolite, Na-P1 and Na-X zeolites. Constr. Build. Mater. 2020, 261, 120016. [CrossRef]

19. Petrella, A.; Di Mundo, R.; De Gisi, S.; Todaro, F.; Labianca, C.; Notarnicola, M. Environmentally Sustainable Cement Composites Based on End-of-Life Tyre Rubber and Recycled Waste Porous Glass. Materials 2019, 12, 3289. [CrossRef]

20. Buratti, C.; Moretti, E.; Belloni, E.; Agosti, F. Development of Innovative Aerogel Based Plasters: Preliminary Thermal and Acoustic Performance Evaluation. Sustainability 2014, 6, 5839-5852. [CrossRef]

21. Nosrati, R.H.; Berardi, U. Hygrothermal characteristics of aerogel-enhanced insulating materials under different humidity and temperature conditions. Energy Build. 2018, 158, 698-711. [CrossRef]

22. Fenoglio, E.; Fantucci, S.; Serra, V.; Carbonaro, C.; Pollo, R. Hygrothermal and environmental performance of a perlite-based insulating plaster for the energy retrofit of buildings. Energy Build. 2018, 179, 26-38. [CrossRef]

23. Pavlíková, M.; Kapicová, A.; Pivák, A.; Záleská, M.; Lojka, M.; Jankovský, O.; Pavlík, Z. Zeolite lightened repair renders: Effect of binder type on properties and salt crystallization resistance. Materials 2021, 14, 3760. [CrossRef]

24. Lubelli, B.; de Rooij, M.R. NaCl crystallization in restoration plasters. Constr. Build. Mater. 2009, 23, 1736-1742. [CrossRef]

25. Brachaczek, W. Microstructure of renovation plasters and their resistance to salt. Constr. Build. Mater. 2018, 182, 418-426. [CrossRef]

26. Barnat-Hunek, D.; Frańczak, M.G.; Klimek, B.; Pavlíková, M.; Pavlík, Z. Properties of multi-layer renders with fly ash and boiler slag admixtures for salt-laden masonry. Constr. Build. Mater. 2021, 278, 122366. [CrossRef]

27. Pavlík, Z.; Pokorný, J.; Pavlíková, M.; Zemanová, L.; Záleská, M.; Vyšvařil, M.; Žižlavský, T. Mortars with Crushed Lava Granulate for Repair of Damp Historical Buildings. Materials 2019, 12, 3557. [CrossRef]

28. Association Francaise de Normalisation (AFNOR). Pozzolanic Addition for Concrete-Metakaolin-Definitions, Specifications and Conformity; NF P 18-513; Association Francaise de Normalisation (AFNOR): La Plaine Saint-Denis, France, 2010.

29. Raverdy, M.; Brivot, F.; Paillére, A.M.; Dron, R. Appréciation de I'Activité Pouzzolanique des Constituents Secondaires. In Proceedings of the 7th International Congress on the Chemistry of Cement, Paris, France, 30 June-4 July 1980; Éditions Septima: Paris, France, 1980; Volume 3, pp. 36-41.

30. Committee for Standardization (CEN). Methods of Test for Mortar for Masonry_Part 3: Determination of Consistence of Fresh Mortar (by Flow Table); EN 1015-3; European Committee for Standardization (CEN): Brussels, Belgium, 1999.

31. Committee for Standardization (CEN). Methods of Test for Mortar for Masonry_Part 10: Determination of Dry Bulk Density of Hardened Mortar; EN 1015-10; European Committee for Standardization (CEN): Brussels, Belgium, 1999.

32. Záleská, M.; Pavlík, Z.; Čítek, D.; Jankovský, O.; Pavlíková, M. Eco-friendly concrete with scrap-tyre-rubber-based aggregateProperties and thermal stability. Constr. Build. Mater. 2019, 225, 709-722. [CrossRef]

33. European Committee for Standardization (CEN). Methods of Test for Mortar for Masonry_Part 11: Determination of Flexural and Compressive Strength of Hardened Mortar; EN 1015-11; European Committee for Standardization (CEN): Brussels, Belgium, 1999.

34. European Committee for Standardization (CEN). Methods of Test for Mortar for Masonry—Part 18: Determination of Water Absorption Coefficient Due to Capillarity Action of Hardened Mortar; EN 1015-18; European Committee for Standardization (CEN): Brussels, Belgium, 2002. 
35. Kumaran, M. Moisture diffusivity of building materials from water absorption measurements. J. Therm. Envel. Build. Sci. 1999, 22, 349-355. [CrossRef]

36. International Organization for Standardization (ISO). Hygrothermal Performance of Building Materials and Product Determination of Water Vapour Transmission Properties; EN ISO 12572; International Organization for Standardization (ISO): Geneva, Switzerland, 2016.

37. Pavlík, Z.; Trník, A.; Keppert, M.; Pavlíková, M.; Žumár, J.; Černý, R. Experimental investigation of the Properties of lime-based plaster-containing PCM for enhancing the heat-storage capacity of building envelopes. Int. J. Thermophys. 2014, 35, 767-782. [CrossRef]

38. European Committee for Standardization (CEN). Nature Stone Test Methods-Determination of Resistance to Salt Crystallization; EN 12370; European Committee for Standardization (CEN): Brussels, Belgium, 2020.

39. Committee for Standardization (CEN). Hygrothermal Performance of Building Materials and Products-Determination of Hygroscopic Sorption Properties; ISO 12571; European Committee for Standardization (CEN): Brussels, Belgium, 2013.

40. Silva, B.A.; Ferreira Pinto, A.P.; Gomes, A. Natural hydraulic lime versus cement for blended lime mortars for restoration works. Constr. Build. Mater. 2015, 94, 346-360. [CrossRef]

41. Faria-Rodrigues, P.; Henriques, F.M.A. Current mortars in conservation: An overview. Restor. Build. Monum. 2004, 10, 609-622. [CrossRef]

42. Fusade, L.; Viles, H.; Wood, C.; Burns, C. The effect of wood ash on the properties and durability of lime mortar for repointing damp historical buildings. Constr. Build. Mater. 2019, 212, 500-513. [CrossRef]

43. da Fonseca, B.S.; Pinto, A.P.F.; Silva, D.V. Compositional and textural characterization of historical bedding mortars from rubble stone masonries: Contribution for the design of compatible repair mortars. Constr. Build. Mater. 2020, 247, 1186277. [CrossRef]

44. Forster, A.M. Building conservation philosophy for masonry repair part 2-'principles'. Struct. Surv. 2010, 28, 165-188. [CrossRef]

45. Maurenbrecher, P. RILEM TC 203-RHM Repair mortars for historic masonry. Requirements for repointing mortars for historic masonry. Mater. Struct. 2012, 45, 1295-1302. [CrossRef]

46. Hughes, J.J. ILEM TC 203-RHM Repair mortars for historic masonry, The role of mortar in masonry an introduction to requirements for the design of repair mortars. Mater. Struct. 2012, 45, 1287-1294. [CrossRef]

47. Nogueira, R.; Pinto, A.P.F.; Gomes, A. Design and behavior of traditional lime-based plasters and renders. Review and critical appraisal of strengths and weaknesses. Cem. Concr. Compos. 2018, 89, 192-204. [CrossRef]

48. Veiga, M.; Aguiar, J.; Silva, A.S.; Carvalho, S.F. Methodologies for characterisation and repair of mortars of ancient buildings. In Historical Constructions; Lourenço, P., Roca, P., Eds.; University of Minho: Guimarães, Portugal, 2001.

49. Papayianni, I. The longevity of old mortars. Appl. Phys. A 2006, 83, 685-688. [CrossRef]

50. Torres, I.; Matias, G.; Faria, P. Natural hydraulic lime mortars-The effect of ceramic residues on physical and mechanical behavior. J. Build. Eng. 2020, 32, 101747. [CrossRef]

51. Garijo, L.; Zhang, X.; Ruiz, G.; Ortega, J.J. Age effect on the mechanical properties of natural hydraulic and aerial lime mortars. Constr. Build. Mater. 2020, 236, 117573. [CrossRef]

52. Grilo, J.; Faria, P.; Veiga, R.; Silva, A.S.; Silva, V.; Velosa, A. New natural hydraulic lime mortars. Physical and microstructural properties in different curing conditions. Construct. Build. Mater. 2014, 54, 378-384. [CrossRef]

53. Pavlíková, M.; Zemanová, L.; Záleská, M.; Pokorný, J.; Lojka, M.; Jankovský, O.; Pavlík, Z. Ternary blended binder for production of a novel type of lightweight repair mortar. Materials 2019, 12, 996. [CrossRef]

54. Hens, H.S. The vapor diffusion resistance and air permeance of masonry and roofing systems. Build. Environ. 2006, 41, 745-755. [CrossRef]

55. Silva, B.A.; Pinto, A.F.; Gomes, A.; Candeias, A. Comparative analysis of the behaviour of integral water-repellents on lime mortars. Constr. Build. Mater. 2020, 261, 120344. [CrossRef]

56. González-Sánchez, J.F.; Fernández, J.M.; Navarro-Blasco, Í.; Alvarez, J.I. Improving lime-based rendering mortars with admixtures. Constr. Build. Mater. 2021, 271, 121887. [CrossRef]

57. Barnat-Hunek, D.; Siddique, R.; Łagód, G. Properties of hydrophobized lighweight mortars with expanded cork. Constr. Built. Mater. 2017, 155, 15-25. [CrossRef]

58. Torres, I.; Matias, G. Sustainable mortars for rehabilitation of old plasters. Eng. Struct. 2016, 129, 11-17. [CrossRef]

59. Dong, X.; Wang, S.; Gong, C.; Lu, L. Effects of aggregate gradation and polymer modifiers on properties of cement-EPS/vitrified microsphere mortar. Constr. Build. Mater. 2014, 73, 255-260. [CrossRef]

60. Jiang, D.; Lv, S.; Cui, S.; Sun, S.; Song, X.; He, S.; Zhang, J.; An, P. Effect of thermal insulation components on physical and mechanical properties of plant fibre composite thermal insulation mortar. J. Mater. Res. Technol. 2020, 9, 12996-13013. [CrossRef]

61. Bai, L.; Xie, J.; Liu, J.; Xie, Y. Effect of salt on hygroscopic properties of cement mortar. Constr. Build. Mater. 2021, $305,124746$. [CrossRef]

62. Darr, J.P.; Davis, S.Q.; Kohno, Y.; McKenna, K.; Morales, P. Morphological effects on the hygroscopic properties of sodium chloride-sodium sulfate aerosols. J. Aerosol Sci. 2014, 77, 158-167. [CrossRef]

63. Martin, S.T. Phase transitions of aqueous atmospheric particles. Chem. Rev. 2000, 100, 3403-3453. [CrossRef]

64. Biskos, G.; Malinowski, A.; Russll, L.M.; Busseck, P.R.; Martin, S.T. Nanosize effect on the deliquescence and the efflorescence of sodium chloride particles. Aerosol Sci. Technol. 2006, 40, 97-106. [CrossRef] 